\title{
Uji Daya Hambat Perasan Bawang Putih terhadap Pertumbuhan Salmonella typhi
}

\author{
Luh Putu Intan Visva Vinenthy ${ }^{1}$, Nur Habibah ${ }^{2}$, I Gusti Ayu Sri Dhyanaputri ${ }^{3}$ \\ Jurusan Teknologi Laboratorium Medis, Politeknik Kesehatan Kemenkes Denpasar, Indonesia \\ Email: nur.habibah.poltekkesdps@gmail.com
}

\begin{abstract}
Inhibitory Potential Test of Garlic Juice against the Growth of Salmonella Typhi. Garlic is one of the herbs that widely used by people to cure the disease, which caused by a bacterial infection. Garlic contains Allicin which has an antibacterial effect on Salmonella typhi. Several studies have been proved that garlic has antibacterial activity against the growth of microbes. This research was conducted to study the potential effect of the garlic juice inhibitory on the growth of Salmonella typhi bacteria. This research was used experimental post-test only control design and disc diffusion method with MHA media. This study was carried out by using four different concentration there were 20,40,60 and 80\%. The negative and positive control was used sterile aqua dest and chloramphenicol. The inhibition zone was determined by observing the clear zone around the disk. The result of the data analysis using the Least Significant Difference (LSD) showed that there was a significant difference between each concentration of the garlic juice. The obtained results proved that garlic juice affects the inhibition zone of Salmonella typhi growth. The largest inhibitory zone was found at the concentration of $80 \%$ with the diameter inhibition zone was $23 \mathrm{~mm}$. This diameter inhibitory zone was classified as a very strong inhibitory effect category. These results concluded that there was a linear correlation between inhibitory potential with the concentration of garlic juice.
\end{abstract}

Keywords: Garlic juice, Inhibitory potential, Inhibition zone, Salmonella typhi

\begin{abstract}
Abstrak: Uji Daya Hambat Perasan Bawang Putih terhadap Pertumbuhan Salmonella Typhi. Bawang putih merupakan salah satu tanaman yang digunakan secara luas oleh masyarakat untuk pengobatan berbagai jenis penyakit, antara lain penyakit yang disebabkan oleh infeksi bakteri. Bawang putih mengandung senyawa Allicin yang dilaporkan memiliki efek antibakteri terhadap bakteri Salmonella typhi. Beberapa penelitian menyebutkan bahwa bawang putih memiliki daya hambat terhadap pertumbuhan bakteri. Penelitian ini bertujuan untuk mengetahui potensi daya hambat perasan bawang putih terhadap pertumbuhan Salmonella typhi. Desain penelitian yang digunakan adalah experimental post-test only control design dengan metode difusi cakram menggunakan media MHA. Penelitian ini menggunakan empat konsentrasi yaitu 20, 40, 60 dan $80 \%$. Kontrol positif dan negatif yang digunakan pada penelitian ini yaitu akuades steril dan kloramfenikol. Zona hambat ditentukan dengan mengamati zona bening yang terbentuk disekeliling cakram. Hasil analisis data pada uji statistik dengan menggunakan uji Least Significant Deference (LSD) menunjukkan bahwa terdapat perbedaan yang bermakna antar konsentrasi perasan bawang putih. Hasil penelitian menunjukkan bahwa seluruh konsentrasi perasan bawang putih mampu menghambat pertumbuhan Salmonella typhi. Diameter zona hambat terbesar ditemukan pada konsentrasi $80 \%$ dengan nilai $23 \mathrm{~mm}$ dan termasuk ke dalam kategori daya hambat sangat kuat. Dapat disimpulkan bahwa terdapat hubungan yang proporsional antara konsentrasi perasan bawang putih dengan potensi daya hambat yang dimiliki.
\end{abstract}

Kata kunci: Perasan bawang putih, potensi daya hambat zona hambat, Salmonella typhi

\section{PENDAHULUAN}

Penyakit infeksi merupakan salah satu jenis penyakit yang memiliki prevalensi cukup tinggi, tidak hanya di Indonesia tetapi juga di dunia. Selain virus, bakteri juga dapat menyebabkan terjadinya penyakit infeksi. Indonesia merupakan negara berkembang dengan angka kejadian infeksi yang tinggi dan didominasi oleh infeksi saluran napas disusul oleh infeksi saluran cerna. Infeksi saluran cerna umumnya disebabkan oleh bakteri golongan Enterobactericeae khususnya Salmonella typhi yang merupakan bakteri patogen dan dapat menimbulkan penyakit demam tifoid pada manusia. Infeksi Salmonella terjadi pada saluran 
cerna dan terkadang menyebar lewat peredaran darah ke seluruh organ tubuh (Lud W,2004).

Penyakit tifoid merupakan salah satu penyakit menular yang penularannya melalui makanan dan minuman yang mengandung Bakteri Salmonella diantaranya yang dikenal adalah Penyebab penyakit ini adalah Salmonella typhi, Salmonella para typhi A, dan Salmonella paratyphi B. Penyakit tifoid merupakan suatu penyakit yang menimbulkan gejala demam panas yang semakin lama semakin meningkat, dengan gejala kepala sakit, menggigil, berkeringat, letih, lemah, tidak ada nafsu makan, dan berat badan berkurang, hal ini dapat mengakibatkan penderita hilang kesadarannya (Mustaki, 2014; Hendrawan, 2008 dalam Sugito dan Slamet, 2018).

Berdasarkan data Kemenkes RI (2012), dilaporkan bahwa kasus demam tifoid dan paratifoid yang terjadi di Indonesia berada diperingkat ke-3 dengan jumlah kasus sekitar 41.000 dengan kasus meninggal sebanyak 274 pasien. Sedangkan menurut data Profil Kesehatan Dinas Kesehatan Provinsi Bali (2014), prevalensi penyakit demam tifoid dan paratifoid pada pasien rawat inap di RSUD di provinsi Bali mencapai 3.254 pasien.

Tingginya prevalensi penyakit demam tifoid ini seharusnya mendapat perhatian yang serius karena permasalahannya yang timbul juga semakin kompleks sehingga mempersulit upaya pencegahan dan pengobatan. Hingga saat ini, pemberian antibiotik merupakan tatalaksana penting dalam menangani pasien dengan penyakit infeksi bakteri. Namun, seiring berjalannya waktu, terjadi perubahan dalam praktik perawatan kesehatan. Hal ini menimbulkan permasalahan baru yaitu munculnya mikroba patogen yang resisten terhadap antibiotik (Mardiastuti, dkk., 2014). Meningkatnya kejadian resistensi antibiotik menjadi penyebab dalam perkembangan infeksi menjadi lebih parah, terjadinya komplikasi, waktu tinggal di rumah sakit yang menjadi lebih lama dan meningkatnya risiko kematian (Anggraini, Opitasari, dan Aini, 2014).

Salmonella typhi merupakan salah satu bakteri gram negatif yang merupakan kuman patogen penyebab demam tifoid, yaitu suatu penyakit infeksi sistemik bersifat akut, ditularkan melalui jalur fekal-oral terutama melalui makanan dan air yang terkontaminasi. Gejala tidak spesifik dan biasanya demam, anoreksia, sakit kepala, mialgia, dan konstipasi. Demam tifoid didahului oleh gastroenteritis, yang biasanya sembuh sebelum timbulnya penyakit sistemik (Kidgell, 2002; Vollard, 2004; Gianella; 1996.
Meningkatnya kejadian resistensi bakteri Salmonella typhi penyebab penyakit demam tifoid terhadap antibiotik merupakan permasalahan serius di bidang kesehatan. Menurut hasil penelitian Sule, et al (2012), diketahui bahwa semua sampel Salmonella typhi hasil isolasi yang diuji 100\% resisten terhadap 6 macam antibiotik dari 10 antibiotik yang diuji. Menurut penelitian tersebut bakteri Salmonella typhi resisten terhadap pefloxacin (PEF), ciprofloxacin (CPX), augmentin (AUG), gentamicin (GEN), co-trimoxazole (COT) dan ampicillin (AMP).

Untuk menanggulangi masalah tersebut, salah satu usaha yang telah lama dikembangkan adalah dengan mengambil jalan alternatif yaitu dengan menggunakan obat-obatan alami berbahan dasar tumbuhan. Banyak tanaman obat yang dilaporkan mempunyai kandungan anti oksidan dan aktivitas antibakteri. Tanaman obat adalah jenis-jenis tanaman yang memiliki fungsi dan berkhasiat sebagai obat dan dipergunakan untuk pencegahan maupun penyembuhan berbagai penyakit (Widhorini, 2019).

Salah satu tumbuhan yang telah lama dipercaya memiliki aktivitas antibakteri yang cukup baik terhadap berbagai macam bakteri ialah bawang putih (Allium sativum L.). Bawang putih telah lama digunakan oleh masyarakat secara luas untuk melawan berbagai penyakit infeksi (Salim, 2016).

Komponen utama dalam bawang putih ialah golongan sulfur diantaranya ialah Diallyl thiosulfinate (allicin) dan juga Diallyl disulfide (ajoene) (Ilic, et al., 2011). Kedua komponen tersebut dilaporkan memiliki aktivitas antibakteri. Kandungan aktif yang terdapat dalam bawang putih ini dilaporkan memiliki kemampuan antara lain menunjukkan sifat antibiotik yang luas terhadap bakteri gram positif dan gram negatif, termasuk terhadap strain yang multi resisten antibiotik, aktivitas antifungi terutama pada strain Candida sp, aktivitas antiviral dan antiparasit, termasuk protozoa usus seperti Giardia lambria dan Entamoeba hystolitica (Salim, 2016).

Penelitian sebelumnya diketahui bahwa infus daun sawo dapat menghambat pertumbuhan Salmonella thypi dengan nilai MIC $30 \% \mathrm{~b} / \mathrm{v}$ dan berpotensi membunuh Salmonella thypi dengan nilai MKC 50\% b/v (Rusdiaman, 2019). Potensi ini disebabkan oleh adanya zat aktif dalam bahan uji seperti flavonoid, saponin dan tanin yang telah dibuktikan pada penelitian sebelumnya (Mayarista, 2013, dalam Rusdiaman, 2019) yang juga terdapat di dalam bawang putih.

Oleh karena itu, peneliti tertarik untuk melakukan penelitian dengan tujuan untuk 
mengetahui potensi daya hambat perasan bawang putih terhadap pertumbuhan bakteri Salmonella typhi.

\section{METODE}

Jenis penelitian yang digunakan adalah true experiment dengan desain penelitian posttest only control group design, dengan menggunakan metode difusi cakram KirbyBauer. Penelitian ini dilaksanakan di Laboratorium Mikrobiologi Jurusan Analis Kesehatan Poltekkes Denpasar pada bulan Februari-April 2019. Objek pada penelitian ini adalah bawang putih segar dengan variasi konsentrasi 20, 40, 60, dan 80\%. Kelompok perlakuan yang digunakan adalah perasan bawang putih dengan konsentrasi $100 \%$ yang kemudian diencerkan dengan akuades steril menjadi konsentrasi 20, 40, 60, dan 80\%. Kontrol negatif yang digunakan adalah akuades steril dan kontrol positif adalah antibiotik kloramfenikol dengan konsentrasi $30 \mu \mathrm{g}$. Pada penelitian ini dilakukan 5 kali pengulangan dengan dua kali replikasi. Data yang diperoleh kemudian dianalisis dengan uji statistik yaitu uji Kolmogorof Smirnof ntuk mengetahui normalitas distribusi data, uji One Way Anova untuk mengetahui kemampuan daya hambat perasan bawang putih terhadap bakteri uji dan uji Least Significant Difference (LSD) untuk mengetahui perbedaan daya masing-masing konsentrasi perasan.

Tahap pengujian dimulai dari pengambilan koloni Salmonella typhi pada media $\mathrm{Na}$ dan biakan murni dengan menggunakan ose. Selanjutnya, dibuat suspensi bakteri menggunakan $\mathrm{NaCl}$ fisiologis $0,95 \%$ sebanyak 5 ml kemudian dihomogenkan sampai diperoleh kekeruhan 0,5 Mc Farland. Suspensi bakteri Salmonella typhi kemudian diinokulasikan secara merata pada media MHA. Sebanyak $20 \mu \mathrm{L}$ perasan bawang putih pada berbagai konsentrasi diteteskan pada cakram disk kosong, kemudian diletakkan pada cawan petri. Sebagai kontrol positif digunakan cakram kloramfenikol $30 \mu \mathrm{g}$ dan kontrol negatif digunakan akuades steril. Selanjutnya, cawan petri diinkubasi selama 24 jam pada suhu $37^{\circ} \mathrm{C}$. Uji daya hambat ditentukan berdasarkan zona bening yang terbentuk disekitar kertas cakram pada cawan petri.

Penelitian ini telah mendapat persetujuan etik (ethical approval) dari Komisi Etik Penelitian Kesehatan (KEPK) Politeknik
Kesehatan Denpasar Nomor

LB.02.03/EA/KEPK/0026/2019.

\section{HASIL}

Data yang diperoleh dari hasil pengukuran diameter zona hambat pertumbuhan Salmonella typhi pada masing-masing konsentrasi perasan bawang putih disajikan pada Tabel 1 .

\begin{tabular}{|c|c|c|c|c|c|c|}
\hline \multirow[t]{2}{*}{$\begin{array}{c}\text { Konsentrasi } \\
(\%)\end{array}$} & \multicolumn{5}{|c|}{$\begin{array}{c}x \text { Diameter zona hambat } \\
\text { Pengulangan } \mathrm{I}-\mathrm{V}(\mathrm{mm})\end{array}$} & \multirow[t]{2}{*}{$\begin{array}{c}x \\
(\mathbf{m m})\end{array}$} \\
\hline & I & II & III & IV & $\mathbf{V}$ & \\
\hline Kontrol (-) & 0 & 0 & 0 & 0 & 0 & 0 \\
\hline 20 & 13 & 13 & 14 & 14 & 15 & 14 \\
\hline 40 & 16 & 16 & 17 & 18 & 17 & 17 \\
\hline 60 & 20 & 20 & 20 & 20 & 20 & 20 \\
\hline 80 & 23 & 21 & 22 & 21 & 22 & 22 \\
\hline Kloramfenikol & 25 & 25 & 25,5 & 25 & 25 & 25,1 \\
\hline
\end{tabular}

Berdasarkan data hasil penelitian yang disajikan pada tabel 1 diketahui bahwa kelompok perlakuan dengan konsentrasi 20, 40, 60 , dan $80 \%$ menghasilkan rerata diameter zona hambat berturut-turut sebesar 14, 17, 20, dan 22 $\mathrm{mm}$. Pada pengujian kontrol positif dengan menggunakan antibiotik kloramfenikol menunjukkan bahwa rerata diameter zona hambat yang diperoleh adalah sebesar 25,1 mm. Hasil pengujian pada kontrol negatif dengan menggunakan akuades steril menunjukkan bahwa tidak terbentuk zona hambat disekitar cakram.

Pada penelitian ini, analisis data dilakukan dengan Uji Kolmogorov Smirnov, One Way Anova dan Least Significant Difference (LSD). Hasil analisis dengan menggunakan uji statistik Kolmogorov Smirnov menunjukkan nilai probabilitas $p$-value $=0,057$. Jika dibandingkan dengan nilai $\alpha(0,05)$, maka nilai $p$-value $>\alpha$ $(0,057>0,05)$. Hasil ini menunjukkan bahwa data yang diperoleh berdistribusi normal, sehingga dapat disimpulkan bahwa varian data yang ada merupakan data homogen. Uji statistik dilanjutkan dengan One Way Anova. Hasil uji parametrik One Way Anova menunjukkan nilai $p$-value $=0,000$ ( $p$-value $<0,05)$. Berdasarkan hasil tersebut dapat disimpulkan bahwa perasan bawang putih memiliki daya hambat terhadap pertumbuhan bakteri Salmonella typhi. Hasil analisis lanjutan dengan uji LSD membuktikan bahwa terdapat perbedaan yang bermakna antara masing-masing konsentrasi perlakuan yang digunakan yaitu 20, 40, 60 dan $80 \%$. 


\section{PEMBAHASAN}

Berdasarkan hasil penelitian yang telah disajikan, diketahui bahwa masing-masing konsentrasi perlakuan memiliki diameter zona hambat yang berbeda-beda. Zona hambat teramati sebagai zona bening di sekeliling cakram uji yang menunjukkan bahwa tidak ada pertumbuhan bakteri Salmonella typhi pada zona bening tersebut. Dalam penelitian ini, zona hambat yang diperoleh pada konsentrasi 20, 40, dan $60 \%$ yaitu sebesar 14, 17 dan $20 \mathrm{~mm}$. Zona hambat tersebut dapat dikategorikan ke dalam daya hambat kuat, karena memiliki rentang nilai antara 11-20 mm. Pada konsentrasi 80\% diperoleh nilai zona hambat sebesar $22 \mathrm{~mm}$. Zona hambat tersebut dapat dikategorikan ke dalam daya hambat sangat kuat, karena memiliki nilai zona hambat $\geq 21 \mathrm{~mm}$.

Perbedaan rerata diameter zona hambat pada pada masing-masing konsentrasi perasan bawang putih terhadap pertumbuhan bakteri Salmonella typhi disajikan pada Gambar 1.

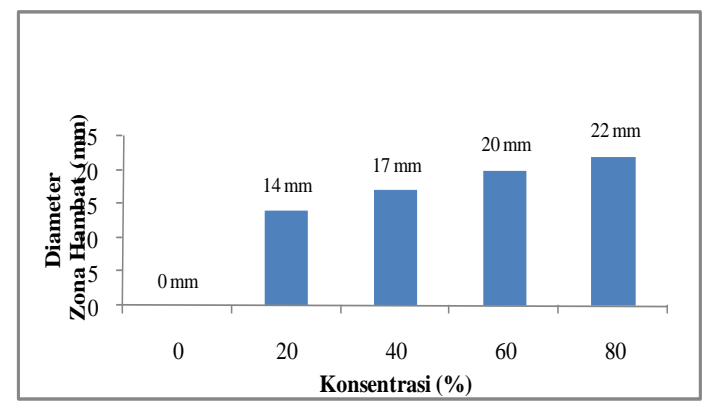

Gambar 1. Rerata Diameter Zona Hambat Perasan Bawang Putih Terhadap Pertumbuhan Salmonella typhi

Berdasarkan hasil penelitian diketahui bahwa perasan bawang putih dengan konsentrasi $20,40,60$, dan $80 \%$ memiliki kemampuan menghambat pertumbuhan bakteri Salmonella typhi. Perbedaan diameter zona hambat yang diperoleh pada masing-masing konsentrasi terjadi karena dipengaruhi oleh adanya perbedaan konsentrasi perasan bawang putih yang digunakan. Semakin tinggi konsentrasi perasan bawang putih, semakin banyak pula kandungan senyawa aktif yang terkandung dalam perasan bawang putih tersebut. Hal ini dibuktikan dengan perbedaan zona hambat yang terbentuk pada tiaptiap konsentrasi. Hasil penelitian yang diperoleh menunjukkan bahwa terdapat hubungan yang proporsional antara konsentrasi perasan bawang putih dengan diameter zona hambat yang dihasilkan. Semakin tinggi konsentrasi perasan bawang putih yang digunakan, semakin luas pula zona hambat yang terbentuk.
Jika dibandingkan dengan konsentrasi yang lain, perasan bawang putih dengan konsentrasi 20\% merupakan bahan uji dengan konsentrasi yang paling encer, sehingga memiliki kandungan zat aktif yang paling sedikit. Semakin sedikit kandungan zat aktif dalam bahan uji akan menghasilkan diameter zona hambat terhadap bakteri Salmonella typhi yang juga semakin kecil (Dewi, Mastra dan Jirna, 2018). Hal ini ditunjukkan dengan zona hambat yang terbentuk pada konsentrasi $20 \%$ yaitu sebesar $14 \mathrm{~mm}$.

Data yang disajikan pada Gambar 1 juga menunjukkan bahwa potensi daya hambat yang paling baik diperoleh pada perasan bawang putih dengan konsentrasi $80 \%$, dengan nilai zona hambat sebesar $22 \mathrm{~mm}$. Pada konsentrasi ini, senyawa aktif yang terkandung dalam perasan bahan uji memiliki jumlah yang paling banyak sehingga memiliki kemampuan yang paling baik dalam menghambat pertumbuhan bakteri Salmonella typhy. Hal ini dibuktikan dengan terbentuknya zona hambat yang paling luas, jika dibandingkan dengan konsentrasi yang lain.

Terbentuknya zona hambat pada penelitian ini dimungkinkan terjadi karena senyawa aktif yang terkandung dalam perasan bawang putih yang telah dijenuhkan pada cakram disk mampu berdifusi secara aktif ke dalam media MHA yang berisi biakan bakteri. Hal ini menyebabkan pertumbuhan bakteri Salmonella typhi terhambat sehingga terbentuk zona bening di sekeliling cakram uji.

Bawang putih memiliki komponen zat aktif utama yaitu diallyl thiosulfinate yang biasa disebut alisin. Allicin merupakan komponen sulfur bioaktif utama yang terkandung dalam bawang putih. Komponen ini akan muncul apabila bawang putih mengalami perubahan struktur fisik bahan, seperti dipotong atau dihancurkan. Pada saat bawang putih dihancurkan, kerusakan membran sel bawang putih ini akan mengaktifkan enzim allinase, yang akan membantu proses metabolisme alliin yang tekandung dalam sel lain, menjadi allicin (Bayan, Kolivand, and Gorji, 2013).

Pada bawang putih utuh, asam amino dan enzim disimpan secara terpisah dalam kompartemen seluler. Namun demikian, ketika bahan tersebut diolah secara fisik, maka penghalang antara kompartemen seluler akan pecah dan allinlyase akan mengkatalisis eliminasi beta dari alin menghasilkan piruvat, amonia, dan asam allysulfenik yaitu dua molekul yang secara spontan bereaksi membentuk diallyl thiosulfinate (allicin). Proses pemerasan pada penelitian ini menyebabkan terjadinya perubahan struktur fisik bawang putih, sehingga senyawa aktif yang 
terkandung dalam bawang putih relatif lebih mudah diperoleh. Selain alisin, senyawa lain yang yang terkandung dalam bawang putih dan berpotensi sebagai senyawa antibakteri antara lain adalah flavonoid, alkaloid, sterol, dan saponin (Sunanti, 2007).

Mekanisme aktivitas antibakteri allisin pada tubuh bakteri dapat terjadi melalui penyerangan DNA, RNA dan sintesis protein. Akan tetapi, target utama dari allisin adalah RNA. Allisin mampu mengganggu produksi RNA dan sintesis lemak. Jika RNA tidak dapat diproduksi atau diproduksi dalam jumlah sedikit, maka sintesis protein dalam tubuh bakteri akan sangat terganggu. Tidak terbentuknya messenger RNA, RNA ribosom dan transfer RNA akan menyebabkan berhentinya sintesis protein. Jika asam amino dan protein tidak dapat dihasilkan, maka pembentukan dan pertumbuhan dari bakteri tersebut tidak akan terjadi (Durairaj, et al., 2009).

Antibiotik kloramfenikol dalam penelitian ini digunakan sebagai kontrol positif dan berperan untuk mengetahui kebenaran metode pengujian yang dilakukan, sehingga terkonfirmasi bahwa bakteri yang digunakan adalah bakteri target yaitu Salmonella typhi. Hasil pengukuran diameter zona hambat pada kontrol positif antibiotik kloramfenikol memperoleh hasil rerata sebesar $25,1 \mathrm{~mm}$. Selanjutnya, hasil pengukuran ini dibandingkan dengan standar CLSI untuk kelompok bakteri Enterobactericeae dan diketahui bahwa zona hambat yang diperoleh termasuk ke dalam kategori sensitif (CLSI, 2017).

Akuades steril dalam penelitian ini digunakan sebagai kontrol negatif yang bertujuan untuk mengetahui pengaruh pelarut yang digunakan terhadap pembentukan diameter zona hambat pada masing-masing konsentrasi perasan bawang putih terhadap pertumbuhan Salmonella typhi. Hasil pengukuran diameter zona hambat kelompok kontrol negatif dalam penelitian ini adalah sebesar $0 \mathrm{~mm}$. Nilai zona hambat ini menunjukkan bahwa akuades steril tidak memiliki zat aktif yang mampu menghambat aktivitas pertumbuhan bakteri Salmonella typhi. Hasil tersebut membuktikan bahwa pelarut yang digunakan tidak berpengaruh terhadap pembentukan zona hambat bakteri Salmonella typhy. Hal ini sekaligus membuktikan bahwa zona hambat yang terbentuk di sekeliling cakram uji disebabkan karena terjadi proses difusi senyawa aktif dari cakram uji ke media MHA. Hasil tersebut membuktikan bahwa perasan bawang putih merupakan salah satu jenis bahan alami yang sangat potensial untuk dikembangkan sebagai senyawa antibakteri, terutama terhadap bakteri Salmonella typhi.

Sejalan dengan penelitian yang dilakukan oleh Suharti, (2005) mengenai anti bakteri dari Temulawak, Jahe, dan Bawang Putih terhadap Salmonella typhi, menunjukkan adanya aktivitas anti bakteri oleh bawang putih terhadap Salmonella typhi.

\section{SIMPULAN}

Berdasarkan hasil penelitian yang diperoleh dapat disimpulkan bahwa perasan bawang putih pada konsentrasi 20, 40, 60 dan $80 \%$ memiliki potensi daya hambat terhadap pertumbuhan bakteri Salmonella typhi dengan diameter zona hambat berturut-turut sebesar 14, 17, 20 dan $22 \mathrm{~mm}$. Daya hambat yang diperoleh pada penelitian ini termasuk ke dalam kategori daya hambat kuat dan sangat kuat. Hasil penelitian ini membuktikan bahwa perasan bawang putih merupakan bahan alami yang sangat potensial untuk dikembangkan sebagai agen antibakteri, terutama terhadap bakteri Salmonella typhi.

\section{DAFTAR PUSTAKA}

Anggraini, A.B., C. Opitasari, and Q. Aini. (2014). The Use Of Antibiotics In Hospitalized Adult Typhoid Patients in an Indonesian Hospital. Health Science Indones, 5(1), pp. 40-43.

http://ejournal.litbang.depkes.go.id/index. php/HSJ/article/download/3530/3485.

Bayan, L., P. H. Koulivand, and A. Gorji. (2013). Garlic A Review Of Potential Therapeutic Effects. Avicenna $J$ Phytomed. $\quad 4 \quad$ (1):7-21. https://www.ncbi.nlm.

nih.gov/pmc/articles/PMC4103721/pdf/ajp -4-001.pdf.

CLSI. (2017). Performance standards for antimicrobial susceptibility testing. (M. L Tertel, J.P Chritopher, L.Martin, and M.A. Russell, Eds.), CLSI supplement M100 $\left(27^{\text {th }}\right.$ ed). Wayne: Clinical and Laboratory Standards Institute.

Dewi, D. G. D. P., N. Mastra, dan I. N. Jirna. (2018). Perbedaan Zona Hambat Pertumbuhan Staphylococcus aureus Pada Berbagai Konsentrasi Ekstrak Etanol Daun 
Biduri Secara In Vitro, Meditory, 6(5), pp. $39-45$.

Dinas Kesehatan Provinsi Blai. 2014. Profil Kesehatan Provinsi Bali. Bali.

Durairaj, S., S. Sangeetha dan P. Lakshmana perumalsamy. (2009). In vitro antibacterial activity and stability of garlic extract at different $\mathrm{pH}$ and temperature. Electronic Journal of Biology. Vol. 5 (1): 5-10.

Gianella RA. (1996). Salmonella. In: Baron S, editor. Medical Microbiology (4th ed). Galveston (TX): University of Texas Medical Branch at Galveston.

Ilic, D. P., V. D. Nikolic, L. B. Nikolic, M. Z. Stankovic, L. P. Stanojevic, and M. D. Cakic. (2011). Allicin and related compounds: biosynthesis and pharmacological activity. Phys Chem Tech. 1: 9-20. http://facta.junis.ni.ac.rs/phat/pcat2011/pc at2011-02.pdf.

Kemenkes RI. (2012). Profil Data Kesehatan Indonesia Tahun 2011. Jakarta: Kementerian Kesehatan Republik Indonesia.

http://www.depkes.go.id/resources/downlo ad/pusdatin/profil-kesehatan-indo nesia/profil-kesehatan-indonesia-2012.pdf.

Kidgell, C., Reichard, U., Wain, J., Linz, B., Torpdahl, M., Dougan, G., \& Achtman, M. (2002). Salmonella typhi, the causative agent of typhoid fever, is approximately 50,000 years old. Infection, Genetics and Evolution, 2(1), 39-45.

Lud W. (2004). Mikrobiologi Umum. Malang: UMM Press Malang.

Mardiastuti H, Karuniawati A, Kiranasari A, dan Kadarsih R. (2014). Emerging Resistance Pathogen. Majalah Kedokteran Indonesia. (3): 75-79. http://indonesia.digitaljournals.org/index.p hp/idnmed/article/download/490/49 1 .

Profil Kesehatan Provinsi Bali. (2014). Dinas Kesehatan Provinsi Bali 2015. http://www.depkes.go.id/resources/ download/profil/PROFIL_KES_PROVIN SI_2015/17_Bali_2015.pdf.

Salim, H.H.U. (2016). Pengaruh Aktivitas Antimikroba Ekstrak Bawang Putih
(Allium sativum L.) terhadap Bakteri Gram Positif (Staphylococcus aureus) dan Gram Negatif (Escherichia coli ) secara In Vitro. [Skripsi]. Lampung: Program Studi Pendidikan Dokter Fakultas Kedokteran Universitas Lampung.

Sule, W.F., A. A. Adige, M. J. Abubakar, and M. O. Ojezele. (2012). Antimicrobial Resistance of clinical isolates of Salmonella typhi in Anyigba, Kogi State, Nigeria', Glob. Adv. Res. J. Microbiol, 1(4), pp. 57-61. http://garj.org/garjm/index.htm.

Sunanti. (2007). Aktivitas Antibakteri Ekstrak Tunggal Bawang Putih (Allium Sativum Linn.) Dan Rimpang Kunyit (Curcuma Domestica Val.) Terhadap Salmonella typhimurium. [Skripsi]. Bogor: Fakultas Matematika dan Ilmu Pengetahuan Alam, Institut Pertanian Bogor.

Suharti, S., Wiryawan, K. G., \& Bintang, M. (2005). Kajian antibakteri temulawak, jahe dan bawang putih terhadap salmonella typhimurium serta pengaruh bawang putih terhadap performa dan respon imun ayam pedaging. Jurnal Ilmu Pengetahuan dan Teknologi Peternakan Media Peternakan, 28(2), 46-99.

Sugito, S., \& Slamet, S. (2018). Daya Hambat Konsentrasi Air Rebusan Cacing Tanah (Lumbricus Rubellus) Terhadap Pertumbuhan Bakteri Salmonella Typhi Dengan Metode Difusi. Jurnal Laboratorium Khatulistiwa, 1(2), 145151.

Vollaard, A. M., Ali, S., van Asten, H. A., Widjaja, S., Visser, L. G., Surjadi, C., \& van Dissel, J. T. (2004). Risk factors for typhoid and paratyphoid fever in Jakarta, Indonesia. Jama, 291(21), 2607-2615.

Widhorini, W., \& Rafianti, R. (2019). Uji Daya Hambat Ekstrak Bawang Merah (Allium cepa L.) terhadap Pertumbuhan Salmonella typhi) pada Media Nutrient Agar (NA. Quagga: Jurnal Pendidikan dan Biologi, 11(2), 99-105. 